\title{
Feed additive effect of Chromolaena odorata on performance of West African dwarf bucks \\ ${ }^{*}$ Oni, A.O, ${ }^{1}$ Ogadu, B., ${ }^{2}$ Yusuf, A. O., ${ }^{1}$ Adelusi, O., ${ }^{2}$ Sowande, O. S. and ${ }^{1}$ Onwuka, C. F. I ${ }^{I}$ Department of Animal Nutrition, ${ }^{2}$ Department of Animal Production and Health,

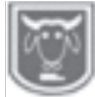 \\ Abstract \\ Federal University of Agriculture, PMB 2240, Abeeokuta, \\ Ogun State, Nigeria \\ *Corresponding author: profoni2003@yahoo.com
}

Efficient rumen fermentation is necessary for improved feed utilization and animal production. The use of feed additives to improve rumen fermentation is promising. Twentyfour West African Dwarf (WAD) bucks with an average weight of $10 \pm 2 \mathrm{~kg}$ were randomly allocated on weight equalization to four treatment diets with 0, 2, 4 and 6\% C. odorata inclusion for a period of three months. Six animals per treatment were used for the study with each animal served as a replicate. Weight changes were taken weekly and digestibility study was carried out. At the end of the study blood samples were also collected for haematological and serum assay. Results showed that the addition of $C$. odorata to the diets influenced $(p<0.05)$ weight gain of experimental goats with goats on diets (4\% inclusion) having the highest value (6.20kg). Nutrient intake, apparent digestibility of nutrients, and nitrogen utilization by WAD goats fed experimental diets were not $(p>0.05)$ affected by dietary inclusion of $C$. odorata. Haematological parameters were not differed ( $p>0.05)$ across the dietary treatments. However, serum glucose and aspartate aminotransferase increased $(p<0.05)$ with increase in inclusion of $C$. odorata. It can be concluded that the use of $C$. odorata as an additive at 4\% inclusion increased weight gain of goats with normal blood ranges indicating no negative effect of goats' health.

Keywords: Chromolaena odorata, performance, blood profile goats

\section{Introduction}

Small ruminants, sheep and goats are increasingly becoming a major source of animal protein among the small holder settlement in Nigeria, contributing over 30 $\%$ to total meat consumption in the country (Lebbie, 2004). Goats are found in all agroecological zones from hyper-arid to superhumid and over the whole range of production systems from intensive smallholder production to very extensive nomadic pastoralism (Payne and Wilson, 1999). With the realization that small ruminants, especially goats are an underused and poorly understood resource, there is a need for a greater understanding of their role, capabilities and outputs that will contribute to the overall productivity of tropical farming systems.

One of the major concerns of ruminant keepers in the tropics is the strategic provision of feed to meet the nutritional requirements of the livestock. In the traditional settings, this demand by the animals is presumptuously met through the basal supply of natural pasture grass which are characterized by low yield and nutrients (Babayemi et al., 2006) as they grow on infertile and erosion degraded soils. The use of field waste or leftovers such as maize stover to feed goats when the available forages are senesced has been a promising option as most agricultural wastes can effectively be put into livestock feeding. However, their availability (in terms of quantity and quality) are of major concerns coupled with high fibre content of these agricultural waste. Moreover, it has been demonstrated that tropical plants (Luecena leucocephala, Chromolaena odorata, Moringa oleifera, Eichhornia crassipes etc) containing certain phytochemicals are possible source of feed to ruminants in the tropics (Puchala et al., 2005). They are 


\section{Feed additive effect of Chromolaena odorata on performance of West African dwarf bucks}

available all year round with high nutritional profile, hence, a good option for the scarce and fibrous forage resource and maize residue. Chromolaena odorata are of high nutritive profile, it contains phytochemicals and it is fairly high in protein. Due to the ubiquitous nature of this plant, there have been numerous researches into its use for livestock nutrition. However, there has been general apathy towards the use of Chromolaena odorata in ruminant nutrition following the reports of its toxicity (Sajise et al., 1974) and the death of some cattle in the Philippines after its ingestion. This was later invalidated by Fadiyimu et al. (2005), who fed six species of weed (Tridax procumbens, Chromolaena odorata, Aspilia africana, Boerhavia diffusa, Ageratum conyzoides and Sida acuta) to a group of West African dwarf goats and reported improved acceptability of Chromolaena odorata. Additionally, Aro et al. (2009) stated that Chromolaena odorata can also be used in the diet of ruminants at a limited quantity and if dried to reduce the presence of anti-nutritional factors. Due to the ubiquitous nature of this plant and its rich protein content with the controversies around it, it is imperative to delve into its possible use in ruminant, hence, this study.

\section{Materials and methods}

\section{Experimental location}

The study was carried out at the Goat Unit of the Institute for Food Security,
Environmental Resource and Agricultural Research (IFSERAR), Federal University of Agriculture, Abeokuta which falls within $7^{\circ} 10^{\prime} \mathrm{N}$ and $3^{\circ} 2^{\prime} \mathrm{E}$ and altitude $76 \mathrm{~m}$ above sea level. It lies in South-Western part of Nigeria with a prevailing tropical climate, a mean annual rainfall of $1,037 \mathrm{~mm}$ and average temperature of $34.7^{\circ} \mathrm{C}$.

\section{Collection of Chromolaena odorata}

Fresh Chromolaena odorata leaves were sourced from the College of Animal Science and Livestock production of Federal University of Agriculture, Abeokuta Farm and within the University environment before inflorescence so as to harvest more leaf. The leaves were air dried until crispy and milled to pass through a $1 \mathrm{~mm}$ sieve and bulked for subsequent analysis and further use.

\section{Animal and management}

Twenty (24) WAD goat bucks averaged $10 \pm 2 \mathrm{~kg}$ were used for the experiment. The animals were reared under intensive management system and maintained under a uniform and constant nutritional regimen with concentrate feed at $300 \mathrm{~g} /$ body weight while maize stover was given ad libitum.

\section{Experimental diets}

Maize stover was harvested $20 \mathrm{~cm}$ above ground level and chopped into small sizes. A complete concentrate diet was formulated to contain $17 \%$ crude protein (Table 1) and Chromolaena odorata leaf meal was included as additive at four (4) levels of 0, 2, 4 and $6 \% / 100 \mathrm{~kg}$ concentrate feed.

Table 1: Gross composition (\%) of experimental concentrate diet

\begin{tabular}{ll}
\hline Feed Ingredients & $\mathbf{\%}$ \\
\hline Maize & 16.00 \\
Soybean & 6.00 \\
Wheat offal & 52.00 \\
Palm kernel cake & 24.00 \\
Bone meal & 1.00 \\
Salt & 1.00 \\
Total & 100 \\
Calculated Nutrient & \\
Crude protein & 17.44 \\
Crude fat & 4.39 \\
Crude fibre & 9.98 \\
Ash & 4.79 \\
\hline
\end{tabular}

*Calculated nutrient did not consider C. odorata 


\section{Oni, Ogadu, Yusuf, Adelusi, Sowande and Onwuka}

\section{Experimental design and data collection}

The animals were divided into four groups of six animals each, which was randomly assigned one of the experimental concentrate diets containing $0,2,4$ and $6 \%$ $C$. odorata addition. The animals were fed the experimental diets for a period of 12 weeks.

\section{Digestibility trial}

At the 10th through 12th week of the feeding trial, four goats were taken from each treatment to the metabolic cage for digestibility trial. The first seven days of the digestibility trial was for the adaptation of the goats to the metabolic cages and the next seven days was for the collection of faecal and urine samples. The samples were bulked together and 10\% aliquot was collected. The bottles for urine collection were rinsed with $10 \%$ sulphuric acid to prevent ammonia volatilization. The quantity of nitrogen retained by the goats was also studied.

\section{Data collection}

\section{Chemical analysis}

Samples taken from the concentrate diet and Chromolaena odorata leaf meal were used for proximate analysis following standard procedure of AOAC (2005) and fibre fraction according to the method of Van Soest et al. (1991). Samples taken from the diets were after the inclusion of the test ingredient

\section{Weight change determination}

Weight change $=$ final weight - initial weight

\section{Feed Conversion Ratio}

Feed conversion ratio $=$ feed intake $/$ weight gain

\section{Blood sample collection and analysis}

Blood samples $(10 \mathrm{~mL})$ were collected at end of the experiments via jugular vein punctured with new hypodermic needle fitted on a new $10 \mathrm{ml}$ calibrated syringe in the morning before feeding and transported in EDTA bottles for heamatological assays and plain bottles for serum studies and then taken to the Veterinary Physiology and
Pharmacology Laboratory, Federal University of Agriculture, Abeokuta for analysis. Haematological parameters such as white blood cell (WBC), lymphocyte, monocyte, neutrophils, eosinophil, basophils, red blood cell (RBC), haemoglobin, pack cell volume, mean corpuscular volume, mean corpuscular haemoglobin, mean corpuscular haemoglobin concentration were determined.

Serum parameters analysed were; blood glucose, serum total protein, serum albumin, serum globulin, alanine aminotransferase (ALT), aspartate aminotransferase (AST) and alkaline phosphatase (ALP). Total protein was determined spectrophotometrically according to the method of Tietz (1995), serum albumin was measured spectrophotometrically according to the method of Donmas et al. (1971) while serum globulin was determined by deducting serum albumin values from total protein values. Serum glucose was assayed with the aid of a photospectrometer according to the method of Barham and Trinder (1972). ALT, AST and ALP were determined following the procedure described by Randox (2012).

\section{Phytochemical screening}

The phytochemical screening of Chromolaena odorata leaf meal for tannin, saponnin, flavonoids, alkaloids and phytates was carried out using the method described by Sofowora (2008).

\section{Statistical analysis}

Data collected during the experimental period were subjected to one-way analysis of variance (ANOVA) in a Completely Randomised Design using SAS (1999) and the means separated using Duncan Multiple Range Test of the same software at $5 \%$ level of significance. The model for the experiment is given below;

$Y i j k=\mu+T j+\sum i j$

Where, Yijk individual observation $\mu=$ population mean 
Tj the effect of Chromolaena odorata

¿ij random residual error

\section{Results}

\section{Chemical properties of $C$. odorata}

The chemical properties of $C$. odorata are presented in Table 2. The values for chemical composition were dry matter (DM) $96.90 \%$, crude protein (CP) $17.51 \%$, crude fibre (CF) $20.43 \%$, ether extract (EE)
$1.39 \%$, ash $8.52 \%$, nitrogen free extract (NFE) 52.16\%, organic matter (OM) $91.48 \%$, neutral detergent fibre (NDF) $62.65 \%$, acid detergent fibre (ADF) $37.77 \%$, acid detergent lignin (ADL) $10.72 \%$, hemicellulose $24.88 \%$ and cellulose $27.05 \%$. For the phytochemicals investigated, the values obtained were saponin $1.99 \%$, tannin $2.57 \%$, flavonoid $1.08 \%$ and alkaloid $1.26 \%$. All parameters were on dry matter basis.

Table 2: Chemical composition of Chromolaena odorata (\%DM)

\begin{tabular}{ll}
\hline Parameters & $(\%)$ \\
\hline Dry Matter & 96.9 \\
Crude Protein & 17.5 \\
Crude Fibre & 20.4 \\
Ether Extract & 1.39 \\
Ash & 8.52 \\
Nitrogen Free Extract & 52.2 \\
Organic Matter & 91.5 \\
Neutral Detergent Fibre & 62.7 \\
Acid Detergent Fibre & 37.8 \\
Acid Detergent Lignin & 10.7 \\
Hemicellulose & 24.9 \\
Cellulose & 27.1 \\
Saponin & 1.99 \\
Tannin & 2.57 \\
Flavonoid & 1.08 \\
Alkaloid & 1.26 \\
Phytate & 1.33 \\
\hline
\end{tabular}

\section{Chemical composition of experimental} concentrate diet and maize stover

The chemical composition of the experimental diets is presented in Table 3. The four experimental diets varied $(\mathrm{P}<0.05)$ in all the proximate parameters and fibre fractions. Diet containing $0 \%$ inclusion of Chromolaena odorata had the highest $(\mathrm{P}<0.05)$ dry matter $(\mathrm{DM})$ content $(93.32 \%)$ while the lowest $(92.05 \%)$ was obtained in the diet with $6 \% C$. odorata inclusion. The highest $(\mathrm{P}<0.05)$ crude protein (CP) value (14.97\%) was observed in the diet with $6 \% C$. odorata inclusion while the lowest $(13.35 \%)$ was recorded in the diet with $0 \% C$. odorata inclusion. The highest $(\mathrm{P}<0.05)$ values $(5.00 \%$ and $9.44 \%)$ for ash and ether extract (EE), respectively, were observed in the diets with $4 \% C$. odorata and 6\% C. odorata inclusion while the least values 3.85 and $8.13 \%$ were recorded for EE and ash in diets with $2 \%$ and $0 \% C$. odorata inclusion for ash and ether extract respectively. For crude fibre, there was difference $(\mathrm{P}<0.05)$ in the percentage, values ranged from $6.21 \%$ $6.52 \%$ with increase in $C$. odorata inclusion. The values for NFE and OM decreased significantly progressively $(\mathrm{P}<0.05)$ from $61.00 \%$ to $56.73 \%$ and $91.87 \%$ to $90.56 \%$ from $0 \%$ to $6 \% C$. odorata inclusion, respectively. There were significant differences $(\mathrm{P}<0.05)$ in the means for NDF and Hemicellulose. Values ranged from $58.14 \%-66.14 \%$ for NDF and $18.57 \%-33.38 \%$ for hemicellulose. The values decreased from $0 \%$ to $6 \%$ level of $C$. odorata inclusion. ADF and cellulose 


\section{Oni, Ogadu, Yusuf, Adelusi, Sowande and Onwuka}

increased significantly $(\mathrm{P}>0.05)$, their values ranged from $32.23 \%-31.69 \%$ for ADF and $28.40 \%-35.23 \%$ for cellulose. The highest $(\mathrm{P}<0.05)$ value $(4.38 \%)$ for ADL was recorded in the diet with $6 \% C$. odorata inclusion while the lowest value (3.58\%) was recorded in the diet with $4 \%$. odorata inclusion. The proximate composition of maize stover determined in this study was; DM 92.95\%, CP 4.38\%, CF $30.80 \%$, EE $0.70 \%$, ash $10.02 \%$, NFE $54.21 \%$, OM 89.99\%, NDF 79.61\%, ADF $19.95 \%$, ADL $5.53 \%$, hemicellulose $59.66 \%$ and cellulose $14.42 \%$.

Table 3: Nutritional composition of experimental concentrate diet and maize stover fed to West African dwarf bucks

\begin{tabular}{|c|c|c|c|c|c|c|c|}
\hline \multirow[b]{2}{*}{ Parameters $(\%)$} & \multirow[b]{2}{*}{$\mathrm{M} \mathrm{S}$} & \multicolumn{3}{|c|}{ Treatment diets } & \multirow[b]{2}{*}{$\mathrm{T}_{4}$} & \multirow[b]{2}{*}{ SEM } & \multirow[b]{2}{*}{$\mathrm{P}$-value } \\
\hline & & $\mathrm{T}_{1}$ & $\mathrm{~T}_{2}$ & $\mathrm{~T}_{3}$ & & & \\
\hline Dry matter & 93.0 & $93.3^{\mathrm{a}}$ & $93.0^{\mathrm{b}}$ & $93.0^{\mathrm{b}}$ & $92.1^{\mathrm{c}}$ & 0.10 & 0.01 \\
\hline Crude protein & 4.28 & $13.6^{\mathrm{d}}$ & $14.0^{\mathrm{c}}$ & $14.1^{\mathrm{b}}$ & $15.0^{\mathrm{a}}$ & 0.13 & 0.01 \\
\hline Crude fibre & 30.8 & $6.21^{\mathrm{b}}$ & $6.30^{\mathrm{b}}$ & $6.45^{\mathrm{a}}$ & $6.52^{\mathrm{a}}$ & 0.03 & 0.05 \\
\hline Ether extract & 0.70 & $4.63^{b}$ & $3.85^{\mathrm{d}}$ & $5.00^{\mathrm{a}}$ & $4.39^{c}$ & 0.10 & 0.01 \\
\hline Ash & 10.0 & $8.13^{\mathrm{d}}$ & $9.13^{\mathrm{c}}$ & $9.30^{\mathrm{b}}$ & $9.44^{\mathrm{a}}$ & 0.12 & 0.01 \\
\hline Nitrogen free extract & 54.2 & $61.0^{\mathrm{a}}$ & $59.5^{\mathrm{b}}$ & $57.8^{\mathrm{c}}$ & $56.7^{\mathrm{d}}$ & 0.33 & 0.01 \\
\hline Organic matter & 90.0 & $91.9^{\mathrm{a}}$ & $90.9^{b}$ & $90.7^{b}$ & $90.6^{\mathrm{c}}$ & 0.12 & 0.01 \\
\hline Neutral detergent fibre & 76.6 & $66.1^{\mathrm{a}}$ & $62.5^{b}$ & $59.2^{c}$ & $58.1^{\mathrm{d}}$ & 0.72 & 0.01 \\
\hline Acid detergent fibre & 18.0 & $32.7^{\mathrm{a}}$ & $35.6^{\mathrm{b}}$ & $38.8^{c}$ & $39.6^{\mathrm{d}}$ & 0.62 & 0.01 \\
\hline Acid detergent lignin & 5.53 & $4.36^{\mathrm{a}}$ & $3.66^{\mathrm{b}}$ & $3.58^{\mathrm{c}}$ & $4.38^{\mathrm{a}}$ & 0.86 & 0.01 \\
\hline Hemicelluloses & 59.7 & $33.4^{\mathrm{a}}$ & $26.9^{\mathrm{b}}$ & $20.4^{\mathrm{c}}$ & $18.5^{\mathrm{d}}$ & 1.34 & 0.01 \\
\hline Cellulose & 14.4 & $28.4^{\mathrm{c}}$ & $32.0^{\mathrm{b}}$ & $35.2^{\mathrm{a}}$ & $35.2^{\mathrm{a}}$ & 0.65 & 0.01 \\
\hline *ME (MJ/Kg DM) & 14.1 & $14.1^{\mathrm{a}}$ & $13.7^{\mathrm{c}}$ & $14.0^{\mathrm{b}}$ & $13.7^{\mathrm{c}}$ & 0.04 & 0.01 \\
\hline
\end{tabular}

\section{Performance characteristics of West} African dwarf bucks fed C. odorata as additive

Table 4 shows the performance characteristics of WAD bucks fed diets with increasing levels of Chromolaena odorata leaf meal additive. The initial weight, final weight, daily concentrate intake, daily maize stover intake, total feed intake and feed conversion ratio were not significantly ( $p>0.05)$ different across the dietary treatments. However, parameters such as weight gain $(\mathrm{kg})$ and daily weight gain $(\mathrm{g})$ were significantly $(\mathrm{p}<0.05)$ differed. The highest value $(6.20 \mathrm{~kg})$ for weight gain was observed in the treatment with $4 \% C$. odorata inclusion while the least value $(4.50 \mathrm{~kg})$ was observed in the diet with $6 \%$ C. odorata inclusion. Likewise, the highest $(\mathrm{p}>0.05)$ value (73.81g) for daily weight gain was recorded in the treatment with $4 \%$ C. odorata inclusion with the lowest value
$(53.87 \mathrm{~g})$ was observed in the diet with $6 \%$ C. odorata inclusion.

Apparent nutrient digestibility of West African dwarf bucks fed diet with Chromolaena odorata leaf meal additive

Table 5 shows the apparent nutrient digestibility of WAD bucks fed diets with $C$. odorata additive. Increasing levels of $C$. odorata had no effect on DM, CP, EE, CF, ash, NFE and OM digestibility.

Nitrogen utilization of West African dwarf bucks fed Chromolaena odorata leaf meal as additive

The result for nitrogen utilization of WAD bucks fed diet with $C$. odorata additive is shown in Table 6 . The values for nitrogen intake from concentrate and maize stover, total nitrogen intake, faecal and urinary nitrogen, total nitrogen excreted, nitrogen absorbed and nitrogen retention were similar $(p>0.05)$ across the dietary treatments. 
Feed additive effect of Chromolaena odorata on performance of West African dwarf bucks

Table 4: Effect of Chromolaena odorata additive on growth performance characteristics of West African dwarf bucks

\begin{tabular}{lllllll}
\hline & \multicolumn{5}{c}{ Treatment Diets } & \\
\cline { 2 - 5 } Parameters & $\mathrm{T}_{1}$ & $\mathrm{~T}_{2}$ & $\mathrm{~T}_{3}$ & $\mathrm{~T}_{4}$ & SEM & P-value \\
\hline Initial weight $(\mathrm{kg})$ & 10.0 & 10.0 & 9.90 & 10.0 & 1.00 & 0.62 \\
Final weight $(\mathrm{kg})$ & 14.8 & 15.1 & 16.1 & 14.5 & 0.53 & 0.76 \\
Weight gain $(\mathrm{kg})$ & $4.80^{\mathrm{b}}$ & $5.00^{\mathrm{ab}}$ & $6.20^{\mathrm{a}}$ & $4.50^{\mathrm{b}}$ & 0.24 & 0.05 \\
Daily weight gain $\left(\right.$ gday $\left.^{-1}\right)$ & $57.1^{\mathrm{b}}$ & $59.5^{\mathrm{ab}}$ & $73.8^{\mathrm{a}}$ & $53.6^{\mathrm{b}}$ & 2.86 & 0.05 \\
Concentrate intake $\left(\right.$ gday $\left.^{-1}\right)$ & 348 & 334 & 346 & 330 & 13.9 & 0.97 \\
Maize intake $\left(\right.$ gday $\left.^{-1}\right)$ & 188 & 188 & 212 & 193 & 17.9 & 0.97 \\
Total feed intake $\left(\right.$ gday $\left.^{-1}\right)$ & 535 & 522 & 558 & 523 & 30.6 & 0.98 \\
Feed conversion ratio & 9.37 & 8.77 & 7.56 & 9.76 & 0.74 & 0.80 \\
\hline
\end{tabular}

$\overline{\mathrm{ab}}$ Means on the same row having different superscripts are significantly different $(\mathrm{p}<0.05)$

$\mathrm{T}_{1}: 0 \%$ C. odorata, $\mathrm{T}_{2}: 2 \%$ C. odorata, $\mathrm{T}_{3}: 4 \%$ C. odorata, $\mathrm{T}_{4}: 6 \%$ C. odorata

Table 5: Effect of Chromolaena odorata addition on apparent nutrient digestibility of West African dwarf bucks

\begin{tabular}{lllllll}
\hline & \multicolumn{5}{c}{ Treatment Diets } & \\
\cline { 2 - 5 } Parameters (\%) & $\mathrm{T}_{1}$ & $\mathrm{~T}_{2}$ & $\mathrm{~T}_{3}$ & $\mathrm{~T}_{4}$ & SEM & P-value \\
\hline Dry matter & 74.9 & 73.7 & 73.9 & 72.9 & 2.39 & 0.99 \\
Crude protein & 83.7 & 83.6 & 84.1 & 83.4 & 0.98 & 0.52 \\
Ether extract & 90.8 & 88.8 & 89.7 & 88.2 & 0.75 & 0.86 \\
Ash & 89.6 & 10.0 & 89.1 & 91.3 & 0.68 & 0.92 \\
Nitrogen free extract & 70.5 & 68.9 & 71.2 & 68.7 & 1.74 & 0.95 \\
Organic matter & 66.6 & 63.7 & 65.8 & 63.3 & 3.21 & 0.98 \\
Crude fibre & 84.3 & 83.5 & 83.4 & 79.9 & 1.92 & 0.88 \\
\hline
\end{tabular}

$\mathrm{T}_{1}: 0 \%$ C. odorata, $\mathrm{T}_{2}: 2 \%$ C. odorata, $\mathrm{T}_{3}: 4 \%$ C. odorata, $\mathrm{T}_{4}: 6 \%$ C. odorata

Table 6: Effect of $C$. odorata addition on nitrogen utilization of West African Dwarf bucks

\begin{tabular}{lcccccc}
\hline & \multicolumn{7}{c}{ Treatment Diets } & & \\
\cline { 2 - 5 } Parameters (\%) & $\mathrm{T}_{1}$ & $\mathrm{~T}_{2}$ & $\mathrm{~T}_{3}$ & $\mathrm{~T}_{4}$ & SEM & P-value \\
\hline Nitrogen Intake (g/day) & 7.43 & 7.46 & 7.82 & 7.90 & 0.31 & 0.94 \\
Concentrate & 1.28 & 1.28 & 1.45 & 1.32 & 0.12 & 0.94 \\
Maize stover & 8.71 & 8.74 & 9.27 & 9.22 & 0.42 & 0.95 \\
Total nitrogen intake (g/day) & & & & & & \\
Nitrogen excretion (g/day) & 1.30 & 1.02 & 1.35 & 1.40 & 0.02 & 0.48 \\
Faecal nitrogen & 0.23 & 0.26 & 0.25 & 0.23 & 0.01 & 1.00 \\
Urinary nitrogen & 1.53 & 1.28 & 1.60 & 1.63 & 0.02 & 0.80 \\
Total nitrogen excreted (g/day) & 7.41 & 7.72 & 7.92 & 7.82 & 0.43 & 0.97 \\
Nitrogen absorbed (g/day) & 7.18 & 7.46 & 7.67 & 7.59 & 0.44 & 0.97 \\
Nitrogen balance (g/day) & 82.4 & 82.3 & 82.7 & 82.3 & 0.62 & 0.99 \\
Nitrogen retention \% & & & & & \\
\hline
\end{tabular}

$\mathrm{T}_{1}: 0 \%$ C. odorata, $\mathrm{T}_{2}: 2 \%$ C. odorata, $\mathrm{T}_{3}: 4 \%$ C. odorata, $\mathrm{T}_{4}: 6 \%$ C. odorata

Blood parameters of West African dwarf bucks fed $C$. odorata as additive

Table 7 shows the blood parameters at the culmination of the experiment of WAD bucks fed $C$. odorata as additive. Glucose and AST were influenced $(\mathrm{p}<0.05)$ by incremental levels of $C$. odorata. Bucks that received $6 \% C$. odorata addition had the highest glucose value $(99.00 \%)$ while the lowest value $(68.00 \%)$ was obtained from bucks fed $4 \% C$. odorata additive. The values for AST increased $(\mathrm{p}>0.05)$ with increase in $C$. odorata inclusion. The values ranged from $59.67 \%$ for bucks on $0 \% C$. odorata inclusion to $75.33 \%$ for bucks on $6 \%$ C. odorata inclusion. Other parameters such as red blood cell, white blood cell, haemoglobin, packed cell volume, lymphocyte, eosinophil, basophil, monocyte, neutrophil, total protein, albumin, globulin, ALT and ALP were comparable $(p>0.05)$ across the dietary treatments. 
Oni, Ogadu, Yusuf, Adelusi, Sowande and Onwuka

Table 7: Effect of $C$. odorata additive on blood parameters of West African dwarf bucks

\begin{tabular}{llllllll}
\hline & & \multicolumn{7}{c}{ Treatment Diets } & & \\
\cline { 3 - 6 } Parameters & $\mathrm{NV}$ & $\mathrm{T}_{1}$ & $\mathrm{~T}_{2}$ & $\mathrm{~T}_{3}$ & $\mathrm{~T}_{4}$ & SEM & P-value \\
\hline Packed cell volume (\%) & $22-38$ & 31.00 & 29.33 & 29.33 & 29.00 & 0.99 & 0.92 \\
& $5-12$ & 5.00 & 5.23 & 5.77 & 5.83 & 0.20 & 0.92 \\
White blood cell (x10\%/L) & $8-18$ & 9.43 & 9.97 & 9.97 & 10.01 & 0.18 & 0.64 \\
Red blood cell (x10 $12 / \mathrm{L})$ & $8-12$ & 8.83 & 9.27 & 9.67 & 9.80 & 0.38 & 0.85 \\
Haemoglobin (g/dL) & $50-70$ & 68.0 & 68.3 & 68.0 & 71.0 & 0.90 & 0.65 \\
Lymphocyte (\%) & $1-8$ & 0.33 & 0.33 & 1.00 & 1.33 & 0.25 & 0.44 \\
Eosinophil (\%) & $0-1$ & 0.67 & 1.00 & 1.33 & 0.67 & 0.19 & 0.63 \\
Basophil (\%) & $25-48$ & 29.0 & 29.3 & 27.3 & 25.0 & 1.06 & 0.51 \\
Neutrophil (\%) & $0-4.0$ & 1.67 & 1.00 & 2.33 & 2.00 & 0.33 & 0.59 \\
Monocyte (\%) & $6.4-7.0$ & 6.27 & 6.50 & 6.80 & 6.53 & 0.11 & 0.44 \\
Total protein (g/dL) & $2.7-3.9$ & 3.27 & 3.07 & 3.63 & 3.70 & 0.13 & 0.31 \\
Albumin (g/dL) & $2.7-5.7$ & 3.00 & 3.43 & 3.17 & 2.83 & 0.10 & 0.18 \\
Globulin (g/dL) & $60-100$ & $90.3^{\mathrm{a}}$ & $75.3^{\mathrm{b}}$ & $68.0^{\mathrm{bc}}$ & $99.0^{\mathrm{ab}}$ & 4.37 & 0.02 \\
Glucose (mg/dL) & $60-167$ & $59.7^{\mathrm{b}}$ & $60.0^{\mathrm{b}}$ & $65.3^{\mathrm{ab}}$ & $75.3^{\mathrm{a}}$ & 2.60 & 0.01 \\
AST (u/l) & $15-52$ & 20.3 & 33.7 & 23.3 & 25.3 & 2.34 & 0.22 \\
ALT (u/l) & $93-287$ & 42.7 & 46.3 & 37.3 & 48.3 & 2.17 & 0.32 \\
ALP (u/l) & & &
\end{tabular}

$\overline{a b c}$ Means on the same row having different superscripts are significantly different $(\mathrm{p}<0.05)$

$\mathrm{T}_{1}: 0 \%$ C. odorata, $\mathrm{T}_{2}: 2 \%$ C. odorata, $\mathrm{T}_{3}: 4 \%$ C. odorata, $\mathrm{T}_{4}: 6 \%$ C. odorata, ALT: Alanine aminotransferase, AST: A spartate aminotransferase, ALP: A lkaline phosphatase, NV: Normal values. Normal values were according to Veterinary manual (2016).

\section{Discussion}

The percentage dry matter recorded for (Siam weed) C. odorata leaf meal in this study was slightly higher than that reported by Aro et al. (2009); Ekeyem et al. (2010); Kawed (2016) who recorded values of $87.40 \%, 91.44 \%$ and $90.49 \%$, respectively. This disparity in dry matter percentages may be due to the varying growth stages of the leaf, seasonal variations in the study areas as influenced by weather condition. Flowering and matured plants tend to have less moisture and more fibre compared to emerging plants, dry matter percentage is always higher during the dry season compared to the rainy season. The crude protein values of $C$. odorata leaf meal in the present study was similar to those reported by Igboh et al. (2009) which was $16.17 \%$, Aro et al. (2009) with $18.67 \%$ and Ekeyem et al. (2010) who reported $16.67 \% \mathrm{CP}$. The value of saponins and tannins in $C$. odorata in this study was lower than that reported by Agaba and Fawole (2016) which were $3.48 \%$ and $4.10 \%$, respectively. However, the value of tannin was higher and that of saponins similar to the report of Igboh et al. (2009) which were $0.37 \%$ and $1.98 \%$, respectively. The percentage of flavonoid and alkaloid were higher than that reported by Agaba and Fawole (2010) and the value of phytate was also higher than the report of Igboh et al. (2009) which were $0.77 \%$, $1.55 \%$ and $0.54 \%$ for flavonoid, alkaloid and phytate, respectively. These slight variations can be attributed to agronomic factor such as stage of maturity of leaf at harvest while the presence of tannin, alkaloid and flavonoid may influence the performance of the experimental animals. The dry matter percentage of maize stover in this study is similar to the reports of Biwi (1986), Tolera and Sundstol (1999), Fabian (2011) who had $93.40 \%, 92.50 \%$ and 93.50\% DM, respectively. However, Fabian (2011) reported a higher crude protein (CP) percentage of $5.60 \%$ compared to that reported in this study. Tolera and Sundstol (1999) had a similar CP percentage of $4.8 \%$ to the one reported in this study. The CP of experimental diets was above 80 g.kg $\mathrm{DM}^{-1}$, the reported 


\section{Feed additive effect of Chromolaena odorata on performance of West African dwarf bucks}

minimum required in diet for adequate digestive activities of rumen microbes (Orskov 1982). The high CP content in the experimental diet is an advantage to rumen microbes that depend on dietary source of nitrogen to build up their body proteins. The increase in crude protein and ash contents of diets with $C$. odorata leaf additive justifies the possible feeding value of the leaf as protein and minerals supplement to feeds with lower level of protein and minerals. Goats fed diet supplemented with $4 \%$ C. odorata leaf meal were most superior in terms of performance characteristics. The improved performance characteristics could be attributed to the high $\mathrm{CP}$ percentage of the diet, higher feed intake, higher $\mathrm{CP}$ intake and higher $\mathrm{CP}$ digestibility compared to other treatments. This suggest that $C$. odorata is a good protein source as it improved feed intake, CP digestibility and CP intake up to $4 \%$ level of inclusion. This result is supported by the observations of Apori et al. (2000) and Kawed (2016) who experimented on WAD and small East African (SEA) goats, respectively, and reported positive performance characteristics of goats fed $C$. odorata supplemented diets. The similar DM, CP, EE, CF, ash and NFE digestibility reported in this study is in line with the reports of Apori (2000) and Kawed (2012) who documented similar DM, CP, EE, CF, ash and NFE digestibility for rabbits and goats fed $C$. odorata supplemented diets, respectively. Silvong (2012) also observe comparable effect on nutrient digestibility of goats fed mulberry supplemented diets. Also, Park et al. (2014) did not observe any effect of Forsythia suspense supplementation on nutrient digestibility of native Korean goats. This is an indication that $C$. odorata inclusion in the concentrate ration of WAD bucks does not have any negative effect on nutrient digestibility and utilization. On the other hand, high fiber and lignin contents have been reported to decrease nutrient digestibility (Mekasha et al., 2002). In this study however, the fibre levels of the diets were not high (6.21 $6.52 \%$ ) of fibre reported by Mekasha et al. (2002), which is another plausible reason for the non-significance observed in apparent nutrient digestibility. The report of Park et al. (2014) who did not observe any effect of Forsythia suspense supplementation on nitrogen utilization of native Korean goats is in accordance with the observation of the current study. $C$. odorata containing saponins did not affect nitrogen retention in this study, indicating that $C$. odorata does not have the ability to alter nitrogen metabolism in the rumen at 2 , 4 and $6 \%$ levels of inclusion. According to Ahamefule et al. (2005) packed cell volume $(\mathrm{PCV})$ is an index of toxicity and its range varies with breeds. In the present study, PCV values were within the physiological range of $22-38 \%$ reported by Krammer (2000) for goats. Aikhuomobhogbe and Orheruata (2006) opined that low PCV results in anaemia, which is associated to reduced oxygen carrying capacity of the blood. The normal PCV values observed in this study is an indication that the treatment diets were nourishing, non-toxic and influenced adequate blood production and supply. The red blood cell (RBC) and white blood cell value (WBC) values were similarly within the normal range for WAD goats reported by Daramola et al. (2005). The RBC values in this study suggests that the diets support good health status of the goats. High WBC count is usually associated with microbial infection or the presence of foreign body or antigen in the circulating medium (Ahamefule et al., 2005). In relation to this study, similar results were reported for haematology of indigenous Pedi goats fed Vachellia karroo leaf meal supplemented diets (Brown et al., 2006). Serum values such as total protein, albumin, globulin, Alanine aminotransferase (ALT) and alkaline phosphatase (ALP) were within normal 


\section{Oni, Ogadu, Yusuf, Adelusi, Sowande and Onwuka}

range for goats reported by (Merck manual 2016). However, aspatate aminotransferase (AST) though within the normal range reported in Merck manual (2016) for goats increased with increasing level of $C$. odorata inclusion. This could be a pointer that $C$. odorata could be toxic to the liver of goats at higher inclusion levels (than those employed in this study) and longer duration of feeding.

\section{Conclusion}

The study showed that addition of $4 \% C$. odorata had the best performance in terms of weight gain and daily weight gain with a similar apparent nutrient digestibility and nitrogen utilization and normal health status in terms of the similar haematological indices. Inclusion of $4 \% C$. odorata to the bucks' diets will improve their immune response as reflected in highest serum protein and albumin values.

\section{Acknowledgement}

The authors thank the World Bank Group for the sponsorship of this research work through the World Bank Africa Centre of Excellence in Agricultural Development and Sustainable Environment (CEADESE), Federal University of Agriculture, Abeokuta, Ogun state, Nigeria.

\section{References}

Agaba, T. A. and Fawole, B. 2016. Phytochemical constituents of siam weed (Chromolaena odorata) and African custard apple (Annona senegalensis). International Journal of Food, Agriculture and Veterinary Sciences, 6 (1): 35-42

Ahamefule, F. O., Ibeawuchi, J. A. and Okoye, F. C. 2005. Blood biochemistry and haematology of WAD bucks fed pigeon pea-cassava based diet. Journal of Animal and Veterinary Advances, 4: 1016-1020.
Aikhuomobhogbe, P. U. and Orheruata, A. M. 2006. Haematology and blood biochemical indices of WAD goats vaccinated against PPR. African Journal of Biotechnology, 5: 743-748.

AOAC 2005. Official methods of analysis, $18^{\text {th }}$ edition. Association of official analytical chemist, Arlington, USA.

Apori, S. O. 2000. Chromolaena odorata, a multipurpose shrub. Forages for Land Reclamation and Rehabilitation 16: 1-3.

Aro, S. O., Osho, I. B., Aletor, V. A. and Tewe, O. O. 2009. Chromolaena odorata in livestock nutrition. Journal of Medicinal Plants Research.3(13): 1253-1257.

Babayemi, O. J., Ajayi, F. T., Taiwo, A. A., Bamikole, M. A. and Fajimi, A. K. 2006. Performance of West African dwarf goats fed Panicum maximum and concentrate diets supplemented with Lablab (Lablab purpureus), Leucaena (Leucaena leucocephala) and Gliricidia (Gliricidia sepium) foliage. Nigerian J. Anim. Prod., 33 (1-2): 102-111

Barham, D. and Trinder, P. 1972. An improved colour reagent for the determination of blood glucose by the oxidase system. Analyst. 97: 142-145.

Bayssa, M., Negesse, T. and Tolera, A. 2016. Effect of supplementation with different proportion of concentrate mixture and untreated or calcium hydroxide treated Acacia toritilis leaf on feed intake, digestibility, nutrient retention and rumen fermentation parameter of Arsi-Bale goats fed Rhodes grass hay basal diet. Iranian Journal of Applied Animal Science, 6(3): 599612.

Biwi, K. M. 1986. The effect of feeding 
sodium hydroxide 'dip' treated and untreated maize stover to lactating dairy cattle. M.Sc. Thesis, Sokoine University of Agriculture, Morogoro. Tanzania.

Casamiglia, S., Busquet, M., Cardozo, P. W., Castillejos, L., Ferret, A. and Fandino, I. 2007. The use of essential oils in ruminants as modifiers of rumen microbial fermentation. Penn state dairy cattle workshop, November $13^{\text {th }}-14^{\text {th }}$ 2007.

Cieslak, A., Szumacher-strabel, M., Stochmal, A. and Oleszek, W. 2012. Plant components with specific activities against rumen methanogens. Animal 7: 252-265.

Daramola, J. O., Adeloye, A. A., Fatoba, T. and Soladoye, A. O. 2005. Haematological and biochemical parameters of West African dwarf goats. Livestock Research for Rural Development. 17: 8-12.

Donmas, B. T., Watson, B. T. and Biggs, H. C. 1971. Albumin standard and the measurement of serum with Bromo Cresol Green. Clinical chim acta. 31:87-96.

Ekeyem, B. U., Obih, T. K. O., Odo, B. I. and Mba, F. I. A. 2010. Performance of finisher broiler chicks fed varying replacement levels of Chromolaena odorata leaf for soyabean meal. Pakistan Journal of Nutrition. 9(6): 558-561.

Fabian, N. F. 2011. The fibrolytic potential of domestic and wild herbivores microbial ecosystems on maize stover. Masters dissertation, College of Agriculture, Engineering and Science University of kwazuluNatal Pietermaritzburg

Fadiyimu, A. A., Alokan, J. A. and Ayodele, A. O. 2005. Nutritional composition and acceptability by West African dwarf goats of some weeds of Nigerian pasture and rangelands. Proceeding $1^{\text {st }}$ annual conference on development in agriculture and biological science. $27^{\text {th }}$ April 2005. Federal university of Technology, Akure, Nigeria. Pp. 92-94.

Igboh, M. N., Ikewuchi, C. J. and Ikewuchi, C. C. 2009. Chemical profile of Chromolaena odorata. Pakistan Journal of Nutrition. 8(5): 521-524.

Kamra, D. N., Agarwal, N. and Chaudhary, L. C. 2006. Inhibition of ruminal methanogenesis by tropical plants containing secondary compounds. Journal of Animal Feed Science technology 129: 156-163.

Kawed, J. S. 2016. Effect of Chromolaena odorata leaf meal on the performance of small East African goats. A Masters dissertation, Sokoine University of Agriculture. Morogoro, Tanzania.

Kongman, P., Wanapat, M., Pakdee, P. and Navanukraw, C. 2010. Effect of coconut oil and garlic powder on in vitro fermentation using gas production techniques. Livestock Science 127: 38-44.

Krammer, J. W. 2000. Normal haematology of cattle, sheep and goat. In Schlam's veterinary haematology. $5^{\text {th }}$ edition, Philadephia, Williams and Wilkins, pp 34-35.

Lebbie, H. B. 2004. Goats under household conditions. Small ruminant research. 52 (2): 131-136.

McGuffey, R. K., Richardson, L. F. and Wilkinson, J. I. D. 2001. Ionophore for dairy cattle: current status and future outlook. Journal of Dairy Science, 84, 194-203.

Mekasha, Y., Tegegne, A., Yami, A. and Umunna, N. N. 2002. Evaluation of non-conventional agro-industrial 


\section{Oni, Ogadu, Yusuf, Adelusi, Sowande and Onwuka}

by-products as supplementary feeds for ruminants: in vitro and metabolism study with sheep. Small Ruminant Research, 44: 25-35.

Nagaraja, T. G., Newbold, C. J., Van Nevel, C. J. and Demeyer, D. I. 1997. Manipulation of rumen fermentation. In: Hobson, P.N., Stewart, C.S. (Eds). The rumen microbial ecosystem (pp. 523-632). London, UK: Chapman and Hall.

Orskov, E. R. 1982. Protein Nutrition in Ruminants. Academic Press, London, UK

Park, N. S., Cho, C. H., Heo, J. M., Song, M., Yang, M. B., Lee, H. S. and Lee, S. K. 2014. Effects of dietary Forsythia suspense on feed utilization, rumen fermentation, and immune response of Korean native goats (Capra hircus). Revista Colombiana de Ciencias Pecuarias, 28: 165-173.

Payne, W. J. A. and Wilson, R. T. 1999. An Introduction to Animal Husbandry in the Tropics. 5th Edition, Blackwell Science, Oxford, 177221.

Puchala, R., Min, B. R., Goetsch, A. L. and Sahlu, T. 2005. The effect of a condensed tannin-containing forage on methane emission by goats. Journal of Animal Science 83:182186.

Sajise, P. E., Palis, R. R., Norcio, N. V. and Lales, J. S. 1974. The biology of Chromolaena odorata (L. King and Robison) 1. Flowering behaviour, pattern of growth and nitrate metabolism. Philippian Weed
Science Bulletin. 1: 17-24.

Silivong, P. 2012. Studies on growth performance and methane emissions in goats fed tree foliages. Master dissertation, Faculty of Agriculture and Applied Biology, Cantho University, Vietnam.

Sofowora, A. 2008. Medicinal plants and traditional medicine in Africa. $3^{\text {rd }}$ Edition, Spectrum Books Limited, Ibadan, Nigeria. Pp. 22-30.

Syadati, S. A., Mirzaei-Aghsaghali, A., Fathi, H. and Davuodi, J. 2012. Importance essential fatty acids (n-6 and $n-3$ ) in animal nutrition: I: Ruminant. Ann. Biol. Res., 3: 11611176.

Tietz, N. W. 1995. Clinical guide to laboratory test, $3^{\text {rd }}$ edition. W.B. Sanders company, Philadephia. Pp 518-519.

Tolera, A. and Sundstol, F. 1999. Morphological fractions of maize stover harvested at different stages of grain maturity and nutritive value of different fractions of the stover. Animal Feed Science and Technology. 81: 1-16.

Van Soest, P. J., Robertson, J. and Lewis, B. 1991. Methods for dietary fiber, neutral detergent fiber, and nonstarch polysaccharides in relation to animal nutrition. Journal of Dairy Science, 74:3583-3597.

Received: $15^{\text {th }}$ November, 2019 Accepted: $17^{\text {th }}$ February, 2020 